\title{
PHYTOCHEMICAL SCREENING AND IN VITRO ANTIOXIDANT ACTIVITY OF WHOLE PLANT EXTRACTS OF SESUVIUM PORTULACASTRUM L
}

\author{
SATHVIKA CHINTALAPANI, SWATHI MS, MANGAMOORI LAKSHMI NARASU*
}

Centre for Biotechnology, Institute of Science and Technology, Jawaharlal Nehru Technological University, Hyderabad, Telangana, India. Email: mangamoori@jntuh.ac.in

Received: 13 September 2017, Revised and Accepted: 24 October 2017

\section{ABSTRACT}

Objectives: The objectives of this study are to screen the phytochemicals, estimate the content of phenolic and flavonoid compounds, and determine the antioxidant capacity of the Sesuvium portulacastrum L. (S. portulacastrum).

Methods: The crude bioactives were extracted from the dried powder of $S$. portulacastrum in an orbital shaker using ethanol, methanol, acetone, hexane, and diethyl ether solvents. Rotaevaporator was used to concentrate the extracts. Total phenolic and flavonoid content was estimated spectrophotometrically using Folin-Ciocalteu and aluminum chloride reagents, respectively. 2,2-diphenyl-1-picrylhydrazyl (DPPH), 2,2'-Azinobis (3-ethylbenzthiazoline-6-sulfonic acid) (ABTS), hydrogen peroxide $\left(\mathrm{H}_{2} \mathrm{O}_{2}\right.$ ), and ferric reducing antioxidant power (FRAP) assays were used to determine the in vitro antioxidant capacity.

Results: Phytochemical screening of the extracts showed the presence of major classes of phytochemicals. Total phenolic content (TPC) expressed as gallic acid equivalents (GAE) ranged from 14.42 (ethanol extract) to 54.05 (diethyl ether extract) mg GAE/g dry weight. Total flavonoid content expressed as quercetin equivalents (QE) ranged from 22.03 (hexane extract) to 56.70 (methanol extract) mg QE/g dry weight. Antioxidant activity determined by different assays is highest in diethyl ether extract. A positive correlation $(0.7241 \leq \mathrm{r} \geq 0.8419)$ was found between the TPC and antioxidant activity determined by DPPH, ABTS, and $\mathrm{H}_{2} \mathrm{O}_{2}$ scavenging assays. Furthermore, there is a strong correlation ( $0.722 \leq \mathrm{r} \geq 0.999$ ) between all the pairs of antioxidant assays.

Conclusion: Diethyl ether extract showed the highest TPC and antioxidant potential among all the extracts of $S$. portulacastrum. Further research has to be done to isolate the pure bioactive compound that has high antioxidant potential.

Keywords: Phytochemical screening, Antioxidant activity, Sesuvium portulacastrum L.

(C) 2018 The Authors. Published by Innovare Academic Sciences Pvt Ltd. This is an open access article under the CC BY license (http://creativecommons. org/licenses/by/4. 0/) DOI: http://dx.doi.org/10.22159/ajpcr.2018.v11i1.22558

\section{INTRODUCTION}

Sesuvium portulacastrum, a mangrove associate, also known as sea purslane belongs to family Aizoaceae. It is a fast-growing, herbaceous, perennial, dichotomous, edible halophyte which grows naturally in the mediterranean, subtropical, coastal, and warmer areas [1]. It is native to five continents: Asia, Africa, Australia, South America, and North America. In India, it grows on the coastal areas of eastern and western regions [2].

S. portulacastrum is used as a remedy for fever and kidney diseases and is also the best-known anecdote for stings of venomous fish. It is also an important source of phytoecdysteroids [3]. Environmentally, the plant has an ability to survive under different abiotic stress conditions such as salinity, drought, and heavy metal accumulation [4].

Free radicals are not harmful to the body when present in low or moderate amounts. They are generated in a number of reactions that are essential to life. Some of them include generation of radicals to kill the invading pathogens by phagocytic cells and those that are involved in intercellular and intracellular signaling. Despite their beneficial activities, reactive oxygen species (ROS) interacts with the molecules within our cells and causes damage to nearby cells, DNA, and mitochondria. Environmental exposure to cigarette smoke, herbicides, and pollution can also generate free radicals in the body [5]. Furthermore, during abiotic stress condition, there is an increase in the production of ROS in plants, which causes damage to DNA proteins and carbohydrates [6].
Antioxidants are the compounds that inhibit the oxidative procedures and lower the harmful effects of free radicals. These compounds also protect the plants from damage caused due to abiotic stress. An imbalance between defensive antioxidants and harmful free radicals will lead to oxidative stress that results in the development of many chronic and degenerative diseases such as cancer, aging, cardiovascular, and autoimmune disorders [7]. The most common free radicals are superoxide $\left(\mathrm{O}_{2}^{-}\right)$, nitric monoxide ( $\left.\mathrm{NO}\right)$, and hydroxyl $(\mathrm{OH})$. Hydrogen peroxide $\left(\mathrm{H}_{2} \mathrm{O}_{2}\right)$ and peroxynitrite (ONOO-) are some of the other molecules that generate free radicals during various chemical reactions [8].

Plant antioxidants are often considered to provide protection against different ailments. Keeping in view the halophytic nature of S. portulacastrum, the presentstudy aims to screen for the phytochemicals present in the plant and study the antioxidant ability of the plant to scavenge the free radicals, thereby decreasing the oxidative and abiotic stress. As phenolic and flavonoid compounds play an important role in the antioxidant defense mechanism, we also aimed to quantitatively estimate the content of phenolic and flavonoid compounds in the plant.

\section{METHODS}

Materials

Quercetin was purchased from Sigma Aldrich. 2,2'-Azino-bis (3-ethylbenzthiazoline-6-sulfonic acid) (ABTS), potassium persulfate $\left(\mathrm{K}_{2} \mathrm{~S}_{2} \mathrm{O}_{8}\right)$, and 2,4,6-tripyridyl-s-triazine (TPTZ) were purchased from Sisco Research Laboratories (SRL, Maharashtra, India). Methanol, acetone, hexane, and diethyl ether were obtained from Fisher Scientific 
(Pittsburg, USA). $\mathrm{H}_{2} \mathrm{O}_{2} 50 \%$ (w/v) was purchased from Qualigens. All the remaining chemicals and solvents were of analytical grade and were obtained from Himedia Laboratories (Mumbai, India).

\section{Collection of plant material}

S. portulacastrum was collected from the forest area of Tirumala hills, Andhra Pradesh. The plant was washed thoroughly with tap water and shade dried to prevent thermal degradation. Air-dried plant was ground to powder and stored at a cool and dry place in the dark airtight containers to avoid oxidation.

\section{Extraction}

For the extraction of crude bioactives, plant powder was initially diluted with different solvents with solvent to sample ratio of 10:1 (v/w). The diluted plant sample was kept at room temperature undisturbed for $24 \mathrm{~h}$. Then, it was kept in the orbital shaker for next $48 \mathrm{~h}$. Solvents ethanol, methanol, acetone, hexane, and diethyl ether were used for the extraction process.

The diluted sample was then filtered through Whatman No. 1 filter paper to obtain crude extracts. Some of the crude extract was separately stored for screening secondary metabolites. The remaining extract was concentrated under reduced pressure at $40^{\circ} \mathrm{C}$ using rotaevaporator. The dried crude concentrated extracts were weighed to calculate the yield percentage and stored at room temperature until further analysis.

\section{Phytochemical screening}

The crude extracts were screened for their secondary metabolites using following procedures $[9,10]$.

\section{Test for alkaloids (Wagner's reagent)}

3-5 drops of Wagner's reagent were added to $2 \mathrm{ml}$ of various extracts. Formation of a reddish-brown precipitate (or coloration) indicates the presence of alkaloids.

\section{Test for carbohydrates (Molisch's test)}

$2 \mathrm{ml}$ of each extract was treated with few drops of Molisch's reagent. This was followed by addition of $2 \mathrm{ml}$ of concentrated sulfuric acid $\left(\mathrm{H}_{2} \mathrm{SO}_{4}\right)$ along the walls of the test tube. The mixture was then allowed to stand for 2-3 min. Formation of a red or dull violet color at the interphase of the two layers indicates the presence of carbohydrates.

\section{Test for cardiac glycosides (Keller Kelliani's test)}

$5 \mathrm{ml}$ of each extract was treated with $2 \mathrm{ml}$ of glacial acetic acid in a test tube, and then, a few drops of $5 \%$ aqueous ferric chloride solution were added to it. This was carefully underlaid with $1 \mathrm{ml}$ of concentrated $\mathrm{H}_{2} \mathrm{SO}_{4}$. A brown ring at the interface indicates the presence of cardiac glycosides.

\section{Test for flavonoids (Alkaline reagent test)}

$2 \mathrm{ml}$ of extract was treated with few drops of $20 \%$ sodium hydroxide solution. Formation of yellow color that becomes colorless with the addition of dilute hydrochloric acid indicates the presence of flavonoids.

\section{Test for phenols (Ferric chloride test)}

Few drops of 5\% aqueous ferric chloride solution was added to $2 \mathrm{ml}$ of each extract and observed for the formation of deep blue or black color.

\section{Test for amino acids and proteins $(1 \%$ ninhydrin solution in ethanol)}

$2 \mathrm{ml}$ of extracts in the test tubes were treated with $2 \mathrm{ml}$ of ninhydrin solution. The test tubes were covered with the foil and were placed in boiling water bath for $5 \mathrm{~min}$. Formation of purple color indicates the presence of amino acids and proteins.

\section{Test for saponins (Foam test)}

$5 \mathrm{ml}$ of water was added to $2 \mathrm{ml}$ of extract. The mixture was shaken vigorously and observed for the formation of persistent foam, which confirms the presence of saponins.
Test for sterols (Liebermann-Burchard test)

$2 \mathrm{ml}$ of extract was treated with few drops of chloroform and acetic anhydride. Then, concentrated $\mathrm{H}_{2} \mathrm{SO}_{4}$ was added carefully along the walls of the test tube and observed for the formation of reddish color.

\section{Test for tannins (Braymer's test)}

$2 \mathrm{ml}$ of $10 \%$ alcoholic ferric chloride solution was added to $2 \mathrm{ml}$ of extract. Formation of greenish color indicates the presence of tannins.

\section{Test for terpenoids (Salkowski's test)}

$2 \mathrm{ml}$ of each extract was treated with $1 \mathrm{ml}$ of chloroform this was followed by the addition of few drops of concentrated $\mathrm{H}_{2} \mathrm{SO}_{4}$. Formation of reddish brown precipitate indicates the presence of terpenoids.

\section{Test for quinones}

$2 \mathrm{ml}$ of extract was treated with few drops of concentrated HCl. Yellow precipitate (or coloration) produced indicates the presence of quinones.

\section{Detection of diterpenes (Copper acetate test)}

$2 \mathrm{ml}$ of each extract was treated with $1 \mathrm{ml}$ of aqueous copper acetate solution. Formation of emerald green indicates the presence of diterpenes.

\section{Tests for resins}

$5 \mathrm{ml}$ of distilled water was added to $2 \mathrm{ml}$ of extract. Turbidity indicates the presence of resins.

\section{Total phenolic content (TPC)}

TPC of different extracts was estimated using Folin-Ciocalteu method described by Alhakmani et al. [11] with few modifications. A calibration curve was constructed with different concentrations of gallic acid (20$100 \mu \mathrm{g} / \mathrm{ml})$ as the standard. $0.3 \mathrm{ml}$ of plant extract $(1000 \mu \mathrm{g} / \mathrm{ml})$ or gallic acid was treated with $1 \mathrm{ml}$ of Folin-Ciocalteu reagent $(1: 10 \mathrm{v} / \mathrm{v})$. After $5 \mathrm{~min}, 2 \mathrm{ml}$ of sodium carbonate solution $(7.5 \%, \mathrm{w} / \mathrm{v})$ was added to the mixture. After $30 \mathrm{~min}$ of incubation at room temperature in the dark, the absorbance of the sample and the standard was measured at $765 \mathrm{~nm}$. Distilled water was used as the reagent blank. The TPC of a sample was determined using linear regression equation obtained from the calibration curve of gallic acid. The content of total phenolic compounds was calculated as mean \pm standard deviation (SD) $(n=3)$ and expressed as mg gallic acid equivalent (GAE)/g dry extract.

\section{Total flavonoid content (TFC)}

TFC of different extracts was determined using aluminum chloride colorimetric method described by Kumari and Sharma [12] with slight modification. A calibration curve was plotted with different concentrations of quercetin $(20-100 \mu \mathrm{g} / \mathrm{ml})$ as the standard. $1 \mathrm{ml}$ of plant extract $(1000 \mu \mathrm{g} / \mathrm{ml})$ or quercetin was mixed with $0.1 \mathrm{ml}$ of $10 \%$ aluminum chloride, $0.1 \mathrm{ml}$ of $1 \mathrm{M}$ potassium acetate, and $2.8 \mathrm{ml}$ of distilled water in a test tube. After $30 \mathrm{~min}$ of incubation at room temperature, the absorbance of the sample and the standard was measured at $415 \mathrm{~nm}$ with ultraviolet-visible spectrophotometer. A solution containing all reagents except aluminum chloride, which is replaced by the same amount of distilled water, is used as a blank. The TFC of sample was determined using linear regression equation obtained from the calibration curve of quercetin. The content of total flavonoid compounds was calculated as mean $\pm S D(n=3)$ and expressed as mg quercetin equivalent $(\mathrm{QE}) / \mathrm{g}$ dry extract.

\section{Antioxidant assays}

2,2-diphenyl-1-picrylhydrazyl (DPPH) assay

The DPPH radical scavenging activity of plant extracts was determined by the method described by Prasanth et al. [13] with slight modification. Ascorbic acid $(2.5-15 \mu \mathrm{g} / \mathrm{ml})$ and butylated hydroxytoluene (BHT) $(10-60 \mu \mathrm{g} / \mathrm{ml})$ were used as the standards. $1 \mathrm{ml}$ of plant extract $(250-1500 \mu \mathrm{g} / \mathrm{ml})$ or standard was treated with $1 \mathrm{ml}$ of $0.2 \mathrm{mM} \mathrm{DPPH}$ solution in ethanol. The reaction mixture was incubated in the dark at room temperature for $90 \mathrm{~min}$. The absorbance of the sample and standards was measured at $517 \mathrm{~nm}$. The ability of the plant extract and 
standard to scavenge the DPPH radical was calculated as the percentage of inhibition using the following formula.

DPPH scavenging activity $(\%)=\left[\left(\mathrm{A}_{\text {Control }}-\left(\mathrm{A}_{\text {Sample- }} \mathrm{A}_{\text {Sample Blank }}\right)\right) / \mathrm{A}_{\text {Control }}\right] \times 100$

Where $A_{\text {control }}$ indicates the absorbance of control containing $1 \mathrm{ml}$ of DPPH and $1 \mathrm{ml}$ of ethanol. $\mathrm{A}_{\text {Sample }}$ is the absorbance of the sample. Due to the high concentration, the sample also absorbs at this wavelength, so it is required to perform blank measurement. $A_{\text {Sample Blank }}$ is the absorbance of sample blank containing $1 \mathrm{ml}$ of plant extract and $1 \mathrm{ml}$ of ethanol. Sample blank is prepared separately for each concentration.

The inhibitory concentration $\left(\mathrm{IC}_{50}\right.$ ) DPPH values (the concentration of sample required for inhibition of $50 \%$ of DPPH radical) were obtained from the linear regression line. The antioxidant activity was evaluated based on this $\mathrm{IC}_{50}$ value.

\section{ABTS assay}

The stock solutions of $7 \mathrm{mM}$ ABTS and $2.45 \mathrm{mM} \mathrm{K}_{2} \mathrm{~S}_{2} \mathrm{O}_{8}$ were prepared in ethanol-water (1:1) mixture [14]. The ABTS reagent was prepared by mixing equal volumes of $\mathrm{ABTS}$ and $\mathrm{K}_{2} \mathrm{~S}_{2} \mathrm{O}_{8}$ stock solutions. The mixture was allowed to react at room temperature for $12-16 \mathrm{~h}$ in the dark to allow the generation of ABTS radical cation $\left(\mathrm{ABTS}^{+}\right)$. The ABTS radical solution was then diluted with ethanol-water mixture to obtain an absorbance of $0.700 \pm 0.020$ at $734 \mathrm{~nm}$. Ascorbic acid (1-3 $\mu \mathrm{g} / \mathrm{ml})$ and BHT $(1-5 \mu \mathrm{g} / \mathrm{ml})$ were used as the standards. To determine the scavenging activity, $1 \mathrm{ml}$ of plant extract $(50-600 \mu \mathrm{g}$ / $\mathrm{ml}$ ) or standard at different concentrations was reacted with $1 \mathrm{ml}$ of diluted ABTS radical solution. The mixture was allowed to incubate at room temperature for $6 \mathrm{~min}$, and the absorbance was recorded at $734 \mathrm{~nm}$. The ability of the plant extract and standard to scavenge the ABTS radical was calculated as a percentage of inhibition using the following formula.

ABTS scavenging activity $(\%)=\left[\left(\mathrm{A}_{\text {Control }}-\left(\mathrm{A}_{\text {Sample- }} \mathrm{A}_{\text {Sample Blank }}\right)\right) / \mathrm{A}_{\text {Control }}\right] \times 100$

Where $A_{\text {Control }}$ indicates the absorbance of control containing $1 \mathrm{ml}$ of diluted ABTS radical solution and $1 \mathrm{ml}$ of ethanol water mixture. $\mathrm{A}_{\text {Sample }}$ is the absorbance of sample. $A_{\text {sample Blank }}$ is the absorbance of sample blank containing $1 \mathrm{ml}$ of ethanol-water mixture and $1 \mathrm{ml}$ of plant extract. Ethanol-water mixture is used as a blank solution. Sample blank is prepared separately for each concentration.

The $\mathrm{IC}_{50}$ ABTS values (the concentration of sample required for inhibition of $50 \%$ of ABTS radicals) were obtained from the linear regression line. The antioxidant activity was evaluated based on this $\mathrm{IC}_{50}$ value.

$\mathrm{H}_{2} \mathrm{O}_{2}$ assay

$\mathrm{H}_{2} \mathrm{O}_{2}$ scavenging activity of plant extracts was determined by the method of Saumya and Basha [15] with slight modification. $20 \mathrm{mM} \mathrm{H}_{2} \mathrm{O}_{2}$ solution was prepared in $50 \mathrm{mM}$ phosphate buffer ( $\mathrm{pH} 7.4)$. Ascorbic acid $(200-1000 \mu \mathrm{g} / \mathrm{ml})$ and BHT $(200-1000 \mu \mathrm{g} / \mathrm{ml})$ were used as the reference standards. To determine the scavenging ability, $1 \mathrm{ml}$ of plant extract $(250-2000 \mu \mathrm{g} / \mathrm{ml})$ dissolved in phosphate buffer or standard was treated with $2 \mathrm{ml}$ of $20 \mathrm{mM} \mathrm{H}_{2} \mathrm{O}_{2}$ solution. After incubation at room temperature for $10 \mathrm{~min}$ in the dark, the absorbance was measured at $230 \mathrm{~nm}$ using quartz cuvette. The ability of the plant extract and standard to scavenge the $\mathrm{H}_{2} \mathrm{O}_{2}$ was calculated as a percentage of inhibition using the following formula.

$\mathrm{H}_{2} \mathrm{O}_{2}$ scavenging activity $(\%)=\left[\left(\mathrm{A}_{\text {Control }}-\left(\mathrm{A}_{\text {Sample- }} \mathrm{A}_{\text {Sample Blank }}\right)\right) / \mathrm{A}_{\text {Control }}\right] \times 100$

Where $A_{\text {Control }}$ indicates the absorbance of control containing $2 \mathrm{ml}$ of $\mathrm{H}_{2} \mathrm{O}_{2}$ and $1 \mathrm{ml}$ of phosphate buffer. $A_{\text {sample }}$ is the absorbance of sample. $A_{\text {Sample Blank }}$ is the absorbance of sample blank containing $2 \mathrm{ml}$ of phosphate buffer and $1 \mathrm{ml}$ of plant extract dissolved in phosphate buffer. Phosphate buffer is used as blank.
The IC $\mathrm{C}_{50} \mathrm{H}_{2} \mathrm{O}_{2}$ values (the concentration of sample required for inhibition of $50 \%$ of $\mathrm{H}_{2} \mathrm{O}_{2}$ molecules) were obtained from the linear regression line. The antioxidant activity was evaluated based on this $\mathrm{IC}_{50}$ value.

\section{Ferric reducing antioxidant power (FRAP) assay}

Ferric reducing ability of plant extracts was measured by the method described by Benzie and Strain [16]. FRAP reagent was a mixture $(10: 1: 1, \mathrm{v} / \mathrm{v} / \mathrm{v})$ of $300 \mathrm{mM}$ sodium acetate buffer (pH 3.6), $10 \mathrm{mM}$ TPTZ in $40 \mathrm{mM} \mathrm{HCl}$ and $\mathrm{FeCl}_{3} \cdot 6 \mathrm{H}_{2} \mathrm{O}(20 \mathrm{mM})$. A calibration curve was plotted with different concentrations of ferrous sulfate $\mathrm{FeSO}_{4}(0.2-1.0 \mathrm{mM})$ as the standard. Ascorbic acid $(100-500 \mu \mathrm{g} / \mathrm{ml})$ and BHT $(100-500 \mu \mathrm{g} / \mathrm{ml})$ were used as the reference standards. To determine the ferric ion reducing ability, $100 \mu \mathrm{L}$ of plant extract $(100-500 \mu \mathrm{g} / \mathrm{ml})$ or standards at different concentrations was treated with $3 \mathrm{ml}$ of freshly prepared FRAP reagent. After incubation at $37^{\circ} \mathrm{C}$ for $30 \mathrm{~min}$, the absorbance was measured at $593 \mathrm{~nm}$. The antioxidant capacity based on the ability to reduce ferric ions of sample was determined using linear regression equation obtained from the calibration curve of $\mathrm{FeSO}_{4}$ and expressed as $\mathrm{mM} \mathrm{FeSO}_{4}$ equivalent per gram of plant extract.

\section{Statistical analysis}

All the experiments were done in triplicates, and the results are expressed as mean \pm SD. Statistical analysis was done using GraphPad Prism 6 Software. Correlation between the means was assessed using Pearson's correlation test. For antioxidant assays, $1 / \mathrm{IC}_{50}$ value was used to determine the correlation. The statistical significance between the means of assays was examined by analysis of variance (ANOVA). A $p<0.05$ was considered as statistically significant.

\section{RESULTS AND DISCUSSION}

\section{Percentage yield of crude extracts}

$50 \mathrm{~g}$ of plant powder was used for extraction with each solvent using an orbital shaker. The percentage of yield with different extracts is shown in Table 1. The yield percentages of different extracts were found in the order ethanol>methanol $>$ acetone $>$ hexane $>$ diethyl ether. Percentage yield of crude extract is more in polar solvents (ethanol, methanol, and acetone) than non-polar solvents (hexane and diethyl ether). From this, we can say that $S$. portulacastrum is rich in polar bioactive compounds.

\section{Phytochemical screening}

Medicinal use of the plants is due to the presence of the phytochemicals that occur naturally in them. Phytochemicals in different crude extracts were estimated qualitatively, and results are shown in Table 2. Alkaloids, carbohydrates, cardiac glycosides, flavonoids, phenols, saponins, sterols, terpenoids, quinones, diterpenes, and resins were present in all the extracts. Ethanol and methanol extracts only revealed the presence of amino acids and proteins. Tannins are present in diethyl ether and hexane extracts. Some of the biological activities that the detected phytochemicals have are anti-inflammatory, antimalarial, antimicrobial, antispasmodic, antidiarrheal, anticancer, and antihelminthic [17] and the ability to treat congestive heart failure and cardiac arrhythmia [18] and other pharmacological effects.

\section{Total phenolic and flavonoid content}

Plant-derived phenolic compounds include phenolic acids, flavonoids, tannins, and the less common stilbenes and lignin. They are a rich source of antioxidants. Phenolics act as antioxidants by scavenging radical species, chelating trace metals such as $\mathrm{Cu}^{+}$or $\mathrm{Fe}^{2+}$ that are responsible

Table 1: Percentage yield with different solvents using orbital shaker

\begin{tabular}{lll}
\hline Solvent & Amount of crude extract obtained (g) & Yield (\%) \\
\hline Ethanol & 2.49 & 4.93 \\
Methanol & 6.99 & 13.98 \\
Acetone & 1.50 & 3.00 \\
Hexane & 0.67 & 1.34 \\
Diethyl ether & 0.98 & 1.96 \\
\hline
\end{tabular}


Table 2: Results of qualitative phytochemical analysis of different extracts

\begin{tabular}{|c|c|c|c|c|c|c|}
\hline Phytochemical compound & Screening test & Ethanol & Methanol & Acetone & Hexane & Diethyl ether \\
\hline Alkaloids & Wagner's reagent test & + & + & + & + & + \\
\hline Carbohydrates & Molisch's test & + & + & + & + & + \\
\hline Cardiac glycosides & Keller Kelliani's test & + & + & + & + & + \\
\hline Flavonoids & Alkaline reagent test & + & + & + & + & + \\
\hline Phenols & Ferric chloride test & + & + & + & + & + \\
\hline Amino acids and protein & Ninhydrin test & + & + & - & - & - \\
\hline Saponins & Foam test & + & + & + & + & + \\
\hline Tannins & Braymer's test & - & - & - & + & + \\
\hline Terpenoids & Salkowski's test & + & + & + & + & + \\
\hline Quinones & Concentrated $\mathrm{HCl}$ test & + & + & + & + & + \\
\hline Diterpenes & Copper acetate test & + & + & + & + & + \\
\hline Resins & Turbidity test & + & + & + & + & + \\
\hline
\end{tabular}

"+" detected "-" not detected

for free radical production. Total phenolics are considered as more powerful antioxidants than Vitamin $\mathrm{C}$ and $\mathrm{E}$ and carotenoids in vitro. Phenolic compounds reduce free radicals by rapidly donating hydrogen atoms and thereby break the chain of reactions that lead to free radical formation. Flavonoids are the most common polyphenols [19].

TPC and flavonoid content of different plant extracts were determined by linear regression equation of gallic acid $(y=0.0091 \times+0.0461$, $\left.r^{2}=0.9936\right)$ and quercetin $\left(y=0.0119 x-0.0921, r^{2}=0.9993\right)$, respectively. The content of total phenolic compounds and flavonoids was calculated and expressed as mg GAE/g dry extract mg QE/g dry extract, respectively (Table 3 ).

Diethyl ether extract contains the highest amount of phenolic compounds, followed by hexane, acetone, methanol, and ethanol. In case of flavonoid content, methanol extract showed the maximum content of flavonoids, followed by ethanol, acetone, diethyl ether, and hexane. TPC is more in non-polar solvents than polar solvents, whereas flavonoid content is more in polar solvents than in non-polar solvents. Furthermore, the TFC increased with increase in polarity of the solvents.

\section{Antioxidant activity}

There are several mechanisms by which antioxidants act. Some of the mechanisms are by donating a hydrogen atom or electron to the radical, scavenging free radical, chelating metal ions, inhibiting $\beta$-carotene bleaching, and quenching singlet oxygen. Based on the chemical reactions involved, major antioxidant assay methods can be divided into two types. They are hydrogen atom transfer (HAT) and single electron transfer (ET). Each assay specifically detects any one of the abilities of antioxidant. Therefore, it is necessary to use more than one type of antioxidant assay [20].

In the present study, antioxidant activity of plant extracts was determined in vitro with different assays such as $\mathrm{DPPH}, \mathrm{ABTS}, \mathrm{H}_{2} \mathrm{O}_{2}$ radical scavenging, and FRAP assays. Among these assays, DPPH and FRAP assays are ETbased assays. On the other hand, ABTS and $\mathrm{H}_{2} \mathrm{O}_{2}$ radical scavenging assays measure the ability of an antioxidant to transfer hydrogen (HAT) to destabilize the free radical, thereby neutralizing it [21].

\section{DPPH assay}

DPPH assay is simple, rapid, economic, and a widely used method to evaluate antioxidant activity. Due to the presence of unpaired electron on DPPH, it shows maximum absorption at $517 \mathrm{~nm}$. The DPPH solution in ethanol appears to be deep violet color. Antioxidant reduces the unpaired electron on DPPH (nitrogen atom of hydrazine contains the odd electron) by donating a hydrogen atom [22]. This results in the decrease in the intensity of the deep violet color of DPPH, which is proportional to the antioxidant activity. Although DPPH assay involves the transfer of hydrogen atom, the underlying chemical reaction is considered to be an ET. This is because the transfer of hydrogen from antioxidant to DPPH is a very slow process and is considered as a
Table 3: Total phenolic and flavonoid contents in different extracts

\begin{tabular}{lll}
\hline Extraction solvent & $\begin{array}{l}\text { Total phenolic } \\
\text { content (mg GAE/g } \\
\text { extract) }\end{array}$ & $\begin{array}{l}\text { TFC (mg QE/g } \\
\text { extract) }\end{array}$ \\
\hline Ethanol & $14.42 \pm 1.54$ & $56.52 \pm 1.63$ \\
Methanol & $15.45 \pm 1.27$ & $56.79 \pm 1.48$ \\
Acetone & $21.45 \pm 2.53$ & $35.55 \pm 0.30$ \\
Hexane & $28.78 \pm 1.52$ & $22.03 \pm 2.15$ \\
Diethyl ether & $54.05 \pm 1.33$ & $24.60 \pm 0.82$ \\
Statistical & $\mathrm{p}<0.0001$ & $\mathrm{p}<0.0001$ \\
significance p value & & \\
\hline
\end{tabular}

TFC: Total flavonoid content, QE: Quercetin equivalent, GAE: Gallic acid equivalents

marginal reaction path, whereas the ET from deprotonated antioxidant to DPPH is a faster and a rate-determining step [23].

The DPPH radical scavenging activity of plant extracts and standards increased with increase in concentration as shown in Fig. 1. The highest activity was found in diethyl ether extract, followed by methanol, acetone, ethanol, and hexane. The DPPH scavenging activity of extracts is significantly lower than standards. Antioxidant activity estimated by DPPH assay showed a positive correlation $(r=0.8419)$ with phenolic content and negative correlation $(r=-0.3052)$ with flavonoid content. Therefore, the ability of the extracts to scavenge the DPPH radical is due to the presence of phenolic compounds rather than flavonoids.

\section{ABTS assay}

ABTS radical cation $\left(\mathrm{ABTS}^{+}\right)$that is blue/green is generated by reacting $\mathrm{ABTS}$ and $\mathrm{K}_{2} \mathrm{~S}_{2} \mathrm{O}_{8}$. ABTS $^{+}$shows maximum absorption at $734 \mathrm{~nm}$. ABTS assay can be used to determine the antioxidant capacity of both hydrophilic and lipophilic samples, as ABTS ${ }^{+}$is soluble in water and organic solvents. In the presence of a hydrogen donating antioxidants, the $\mathrm{ABTS}^{+}$reduces back to ABTS that is colorless at $734 \mathrm{~nm}$. The antioxidant activity is proportional to the decrease in the absorbance [24].

The ABTS radical scavenging activity of plant extracts and standards increased in a concentration-dependent manner as seen in Fig. 2. Diethyl ether extract showed the highest activity, followed by methanol, ethanol, acetone, and hexane. The scavenging activity of plant extracts is much lower than standards. All the extracts except hexane extract showed $90 \%$ scavenging activity at a concentration of $600 \mu \mathrm{g} / \mathrm{ml}$. The ABTS scavenging activity of the extracts shows a positive correlation $(\mathrm{r}=0.8368)$ with the phenolic content but is negatively correlated $(r=-0.2894)$ with the flavonoid content.

\section{$\mathrm{H}_{2} \mathrm{O}_{2}$ scavenging assay}

$\mathrm{H}_{2} \mathrm{O}_{2}$ is a non-free radical, as it has no unpaired electrons. $\mathrm{H}_{2} \mathrm{O}_{2}$ directly does not cause damage to the cells, but it is converted to highly reactive 
hydroxyl radical $(\mathrm{OH})$, which causes damage to DNA. Thus, ability of scavenging $\mathrm{H}_{2} \mathrm{O}_{2}$ is one of the measures of antioxidant activity [25]. $\mathrm{H}_{2} \mathrm{O}_{2}$ is a strong oxidizing agent, which undergoes reduction by accepting hydrogen from the antioxidant. $\mathrm{H}_{2} \mathrm{O}_{2}$ is neutralized to $\mathrm{H}_{2} \mathrm{O}$ during this process. This decrease in the absorbance of $\mathrm{H}_{2} \mathrm{O}_{2}$ at $230 \mathrm{~nm}$ is proportional to the activity of the antioxidant.

The effect of concentration on the $\mathrm{H}_{2} \mathrm{O}_{2}$ scavenging activity of plant extracts and standards is shown in Fig. 3 . The $\mathrm{H}_{2} \mathrm{O}_{2}$ scavenging activity of diethyl ether extract is greater than ascorbic acid at $250 \mu \mathrm{g} / \mathrm{ml}$. Furthermore, the activity of diethyl ether extract is higher than BHT at $250 \mu \mathrm{g} / \mathrm{ml}$ as well as $500 \mu \mathrm{g} / \mathrm{ml}$. However, the $\mathrm{IC}_{50}$ value of the diethyl ether extract is higher than that of standards. The decreasing order of magnitude of activity of extracts is diethyl ether, methanol, ethanol, acetone, and hexane. In case of hexane extract, there is nonlinear (exponential) relation between the concentration and inhibition percentage. Rest of the extracts showed a linear relation. There is a positive correlation $(\mathrm{r}=0.7241)$ between $\mathrm{H}_{2} \mathrm{O}_{2}$ scavenging activity and phenolic content of the plant. There is almost no correlation $(\mathrm{r}=-0.0980)$ between the antioxidant determined by $\mathrm{H}_{2} \mathrm{O}_{2}$ scavenging assay and flavonoid content of the extracts.

\section{FRAP assay}

The FRAP assay is based on the ability of antioxidants to reduce the ferric TPTZ complex [Fe(III)-(TPTZ) $]_{2}^{3}$ to the intensely blue-colored ferrous complex $\left[\mathrm{Fe}(\mathrm{II})-(\mathrm{TPTZ})_{2}\right]^{2+}$ in acidic medium. FRAP values are

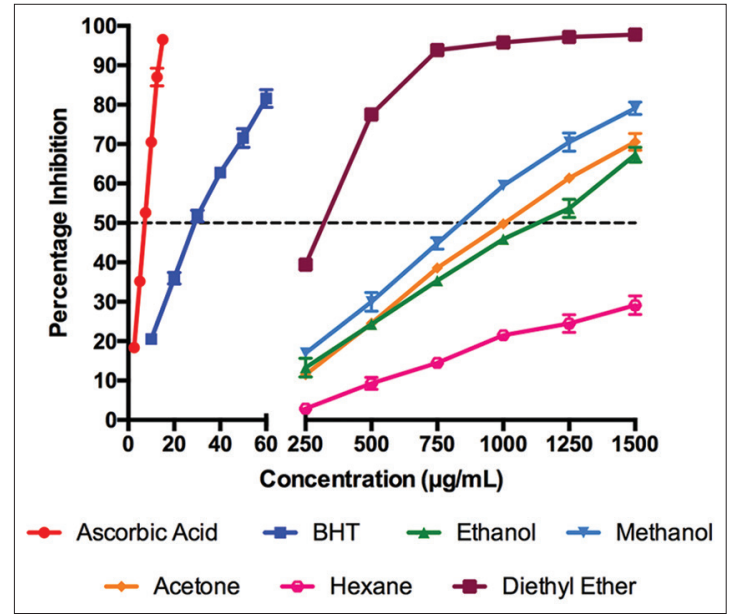

Fig. 1: 2,2-diphenyl-1-picrylhydrazyl scavenging activity of plant extracts and standards

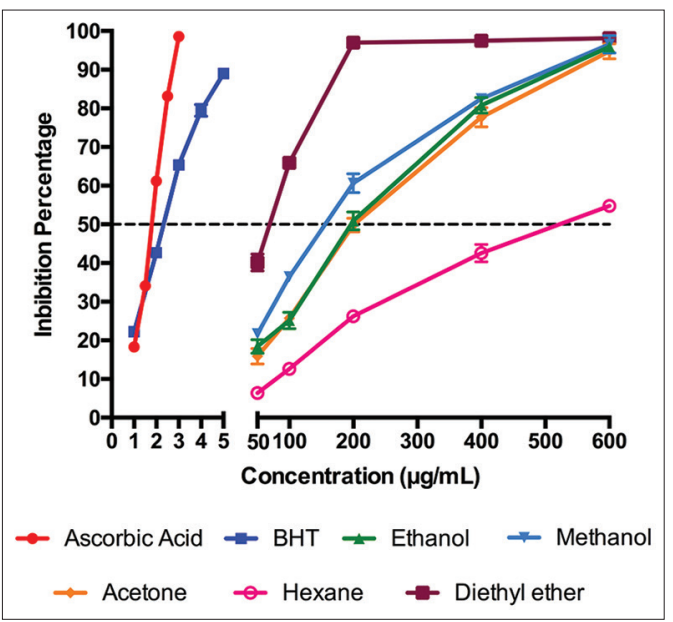

Fig. 2: 2,2'-Azino-bis (3-ethylbenzthiazoline-6-sulfonic acid) radical scavenging activity of plant extracts and standards calculated by measuring the increase in the absorbance at $593 \mathrm{~nm}$ and expressing them as $\mu \mathrm{M}$ ferrous ion $\left(\mathrm{Fe}^{2}\right)$ equivalents [26]. The results of FRAP assay obtained with different extracts of $S$. portulacastrum are shown in Fig. 4

At a concentration of $100 \mu \mathrm{g} / \mathrm{ml}$, the reducing activity of the extracts is of the order methanol>diethyl ether $>$ ethanol $>$ acetone $>$ hexane. At a concentration 200 and $300 \mu \mathrm{g} / \mathrm{ml}$, the order of the reducing activity is diethyl ether $>$ methanol $>$ acetone $>$ ethanol $>$ hexane. At the concentration of 400 and $500 \mu \mathrm{g} / \mathrm{ml}$, diethyl ether showed the highest reducing power, followed by methanol, ethanol, acetone, and hexane. The antioxidant capacity determined by FRAP assay showed a little or no correlation with phenolic content $(0.3462 \leq \mathrm{r} \geq 0.5375)$ and the flavonoid content $(0.0543 \leq r \geq 0.3177)$.

\section{Correlations between antioxidant assays}

Antioxidant properties were evaluated and expressed as $\mathrm{IC}_{50}$ values (Table 4). Lower $\mathrm{IC}_{50}$ values indicate higher antioxidant activity. The order of ability of different extracts to scavenge DPPH and $\mathrm{H}_{2} \mathrm{O}_{2}$ radical is diethyl ether $>$ methanol $>$ ethanol $>$ acetone $>$ hexane. For the ABTS radical scavenging activity, the activity of different extracts was in the order of diethyl ether>methanol>acetone>ethanol>hexane. In all the assays, diethyl ether showed the highest activity, and hexane showed the least activity. Statistical analysis was used to find the correlations between antioxidant activities determined by different assays. Strong positive correlation was found between ABTS and DPPH assays ( $r=0.999)$, ABTS

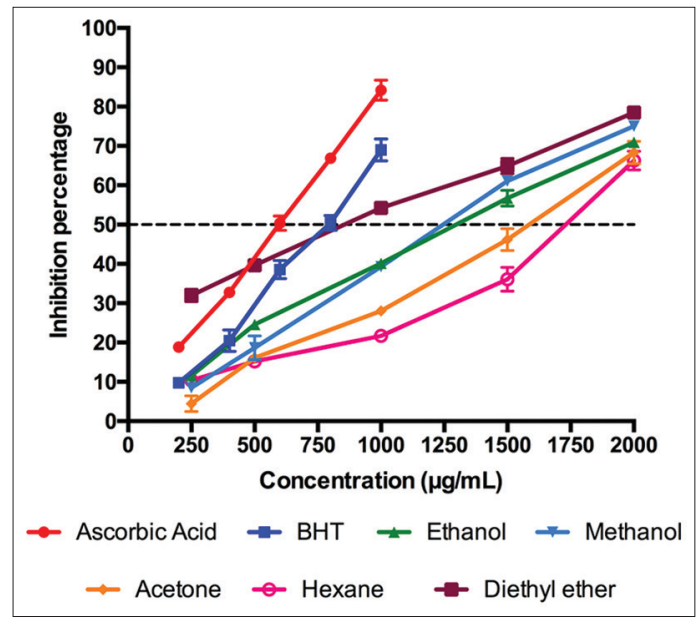

Fig. 3: Hydrogen peroxide scavenging activity of plant extracts and standards

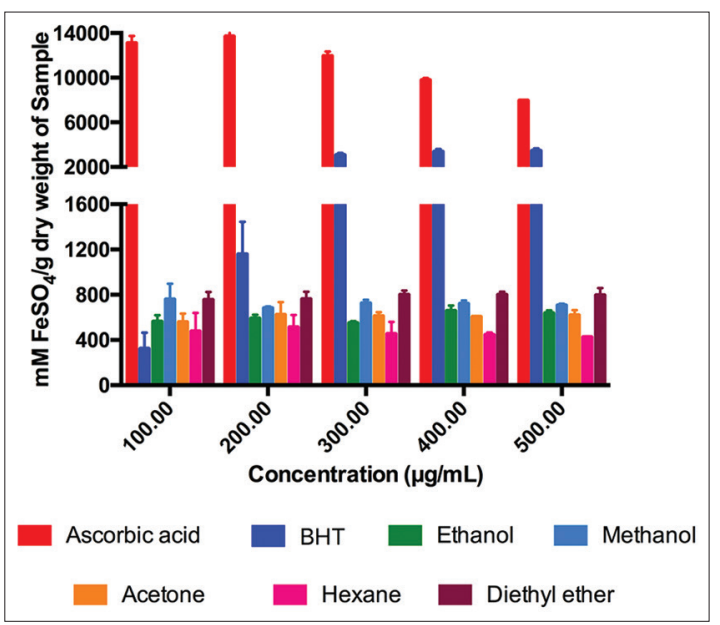

Fig. 4: Ferric reducing antioxidant power of plant extracts and standards 
Table 4: $\mathrm{IC}_{50}$ values of all the extracts in DPPH, ABTS, and $\mathrm{H}_{2} \mathrm{O}_{2}$ assays

\begin{tabular}{llll}
\hline \multirow{2}{*}{ Extract } & \multicolumn{1}{|c}{$\mathbf{I C}_{50}(\mu \mathbf{g} / \mathbf{m l})$} & & \\
\cline { 2 - 4 } & $\mathbf{D P P H}$ & ABTS & $\mathbf{H}_{2} \mathbf{O}_{2}$ \\
\hline Ascorbic acid & $7.19 \pm 0.13$ & $1.78 \pm 0.01$ & $593.20 \pm 14.58$ \\
BHT & $31.68 \pm 1.02$ & $2.43 \pm 0.04$ & $766.45 \pm 27.62$ \\
Ethanol & $1114.66 \pm 41.36$ & $240.75 \pm 11.54$ & $1327.72 \pm 28.29$ \\
Methanol & $871.67 \pm 18.42$ & $197.32 \pm 5.05$ & $1293.77 \pm 14.32$ \\
Acetone & $1027.56 \pm 4.79$ & $250.66 \pm 5.11$ & $1549.93 \pm 69.30$ \\
Hexane & $2461.45 \pm 195.59 *$ & $515.21 \pm 7.35$ & $1741.50 \pm 31.69$ \\
Diethyl ether & $289.99 \pm 3.47$ & $68.67 \pm 4.49$ & $902.77 \pm 49.04$ \\
\hline
\end{tabular}

${ }^{*}$ The $\mathrm{IC}_{50}$ value of the hexane extract was obtained from the extrapolation of the graph between the concentration and inhibition percentage. $\mathrm{IC}_{50}$ : Inhibitory concentration, DPPH: 2,2-diphenyl-1-picrylhydrazyl, ABTS: 2,2'-Azino-bis (3-ethylbenzthiazoline-6-sulfonic acid), $\mathrm{H}_{2} \mathrm{O}_{2}$ : Hydrogen peroxide, BHT: Butylated hydroxytoluene

and $\mathrm{H}_{2} \mathrm{O}_{2}$ assays ( $\mathrm{r}=0.976$ ), and DPPH and $\mathrm{H}_{2} \mathrm{O}_{2}$ assays ( $\mathrm{r}=0.969$ ) which is in accordance with reports suggested by other authors [27]. FRAP assay showed comparatively moderate positive correlation with DPPH ( $\mathrm{r}=0.722)$, ABTS $(\mathrm{r}=0.727)$, and $\mathrm{H}_{2} \mathrm{O}_{2}$ assays $(\mathrm{r}=0.789)$.

Several authors have reported a significant positive relationship between the phenolic compounds with their free radical scavenging activity $[28,29]$. Therefore, the high content of phenolic compounds in diethyl ether extract explains its high antioxidant potential that is evident from its low $\mathrm{IC}_{50}$ values when compared to other extracts.

\section{CONCLUSION}

The phytochemical screening of all the extracts showed the presence of many phytochemicals that are biologically important. The total phenolic and flavonoid content of the plant is comparable to other medicinal plants. To increase the antioxidant potential of the plant, the pure active compound that has the ability to scavenge the free radicals should be isolated. The isolated compound, which has high antioxidant activity, could be used in curing many oxidative stress-related diseases such as cancer, cardiovascular, and other chronic diseases.

\section{AUTHOR CONTRIBUTION}

Conception and design of the work was done by Prof. Mangamoori and Ms. Chintalapani. Data was acquired by Ms. Chintalapani and Ms. Swathi. Statistical analysis, interpretation of data and drafting of the article was done by Ms. Chintalapani. Critical revision of the article was done by Prof. Mangamoori and Ms. Chintalapani

\section{CONFLICT OF INTEREST}

We declare that there is no conflict of interest

\section{REFERENCES}

1. Ramani B, Reeck T, Debez A, Stelzer R, Huchzermeyer B, Schmidt A, et al. Aster tripolium L. and Sesuvium portulacastrum L.: Two halophytes, two strategies to survive in saline habitats. Plant Physiol Biochem 2006; 44:395-408.

2. Lokhande VH, Nikam TD, Ghane SG, Suprasanna P. In vitro culture, plant regeneration and clonal behaviour of S. portulacastrum (L.) L.: A prospective halophyte. Physiol Mol Biol Plants 2010;16:187-93.

3. Rojas A, Hernandez L, Pereda-Miranda R, Mata R. Screening for antimicrobial activity of crude drug extracts and pure natural products from Mexican medicinal plants. J Ethnopharmacol 1992;35:275-83.

4. Slama I, Ghnaya T, Savouré A, Abdelly C. Combined effects of longterm salinity and soil drying on growth, water relations, nutrient status and proline accumulation of Sesuvium portulacastrum. C R Biol 2008;331:442-51.
5. Bhattacharyya A, Chattopadhyay R, Mitra S, Crowe SE. Oxidative stress: An essential factor in the pathogenesis of gastrointestinal mucosal diseases. Physiol Rev 2014;94:329-54.

6. Gill SS, Tuteja N. Reactive oxygen species and antioxidant machinery in abiotic stress tolerance in crop plants. Plant Physiol Biochem 2010;48:909-30.

7. Rajkapoor B, Burkan ZE, Kumar RS. Oxidants and human diseases: Role of antioxidant medicinal plants-A review. Pharm Online 2010;1:1117-31.

8. Gilgun-Sherki Y, Melamed E, Offen D. Oxidative stress inducedneurodegenerative diseases: The need for antioxidants that penetrate the blood brain barrier. Neuropharmacology 2001;40:959-75.

9. Ganesh S, Vennila JJ. Phytochemical analysis of Acanthus ilicifolius and Avicennia officinalis By GC-MS. Res J Phytochem 2011;5:60-5.

10. Gochukwu SC, Uche AI, Ifeanyi O. Preliminary phytochemical screening of different solvent extracts of stem bark and roots of Dennetia tripetala G. Baker. Asian J Plant Sci Res 2013;3:10-3.

11. Alhakmani F, Kumar S, Khan SA. Estimation of total phenolic content, in-vitro antioxidant and anti-inflammatory activity of flowers of Moringa oleifera. Asian Pac J Trop Biomed 2013;3:623-7.

12. Kumari A, Sharma RA. Estimation of total phenol, flavonoid contents and DPPH free radical scavenging activity of Oxalis corniculata Linn. Int J Bio Pharm Res 2015;6:178-81.

13. Prasanth NV, Dilip C, Dev KT, Augustine L, Saraswathi R. Evaluation of in-vitro cytotoxic and antioxidant activities of Ipomoea batatas. Int J Pharm Pharm Sci 2010;2:91-2.

14. Guedes AC, Amaro HM, Gião MS, Malcata FX. Optimization of ABTS radical cation assay specifically for determination of antioxidant capacity of intracellular extracts of microalgae and cyanobacteria. Food Chem 2013;138:638-43.

15. Saumya $\mathrm{S}$, Basha P. In vitro evaluation of free radical scavenging activities of Panax ginseng and Lagerstroemia speciosa: A comparative analysis. Int J Pharm Pharm Sci 2010;3:165-9.

16. Benzie IF, Strain JJ. The ferric reducing ability of plasma (FRAP) as a measure of "antioxidant power": The FRAP assay. Anal Biochem 1996;239:70-6.

17. Tiwari P, Kumar B, Kaur M, Kaur G, Kaur H. Phytochemical screening and extraction: A Review. Int Pharm Sci 2011:1:98-106.

18. Kren V, Martínková L. Glycosides in medicine: "The role of glycosidic residue in biological activity". Curr Med Chem 2001;8:1303-28.

19. Dai J, Mumper RJ. Plant phenolics: Extraction, analysis and their antioxidant and anticancer properties. Molecules 2010;15:7313-52.

20. Antolovich M, Prenzler PD, Patsalides E, Mcdonald S, Robards K. Methods for testing antioxidant activity. Analyst 2001;127:183-98.

21. Badarinath AV, Mallikarjuna K, Sudhana Chetty CM, Ramkanth S, Rajan TV, Guanaprahash K. A review on in vitro antioxidant methods: Comparisions, correlations and considerations. Int J PharmTech Res 2010;2:1276-85.

22. Kedare SB, Singh RP. Genesis and development of DPPH method of antioxidant assay. J Food Sci Technol 2011;48:412-22.

23. Huang D, Ou B, Prior RL. The chemistry behind antioxidant capacity assays. J Agric Food Chem 2005;53:1841-56.

24. Boligon AA. Technical evaluation of antioxidant activity. Med Chem 2014:4:517-22.

25. Umamaheswari M, Chatterjee TK. In vitro antioxidant activities of the fractions of Coccinia grandis L. Leaf extract. Afr J Tradit Complement Altern Med 2007;5:61-73

26. Magalhães LM, Segundo MA, Reis S, Lima JL. Methodological aspects about in vitro evaluation of antioxidant properties. Anal Chim Acta 2008;613:1-9.

27. Thaipong K, Boonprakob U, Crosby K, Cisneros-Zevallos L, Hawkins Byrne D. Comparison of ABTS, DPPH, FRAP, and ORAC assays for estimating antioxidant activity from guava fruit extracts. J. Food Compos. Anal 2006;19:669-75

28. Trabelsi N, Megdiche W, Ksouri R, Falleh H, Oueslati S, Bourgou S, et al. Solvent effects on phenolic contents and biological activities of the halophyte Limoniastrum monopetalum leaves. Lebenson Wiss Technol 2010;43:632-9.

29. Piluzza G, Bullitta S. Correlations between phenolic content and antioxidant properties in twenty-four plant species of traditional ethnoveterinary use in the mediterranean area. Pharm Biol 2011;49:240-7. 